Journal of Southeast Asian

2013

\title{
Book Review: I Love Yous Are for White People, by Lac Su
}

Quan Manh $\mathrm{Ha}$

University of Montana, quan.ha@mso.umt.edu

Follow this and additional works at: https://docs.lib.purdue.edu/jsaaea

\section{Recommended Citation}

Ha, Quan Manh (2013) "Book Review: I Love Yous Are for White People, by Lac Su," Journal of Southeast Asian American Education and Advancement: Vol. 8 : Iss. 1, Article 5.

DOI: $10.7771 / 2153-8999.1060$

Available at: https://docs.lib.purdue.edu/jsaaea/vol8/iss1/5

This document has been made available through Purdue e-Pubs, a service of the Purdue University Libraries. Please contact epubs@purdue.edu for additional information.

This is an Open Access journal. This means that it uses a funding model that does not charge readers or their institutions for access. Readers may freely read, download, copy, distribute, print, search, or link to the full texts of articles. This journal is covered under the CC BY-NC-ND license. 


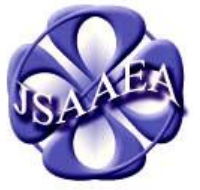

Volume 8 (2013)
Journal of Southeast Asian American

Education \& Advancement

WWW.JSAAEA.org
A peer-reviewed

scholarly journal

published by the

National Association

for the Education \&

Advancement of

Cambodian, Laotian,

and Vietnamese

Americans (NAFEA)

\title{
Su, Lac. (2009). I Love Yous Are for White People. New York, NY: Harper Perennial. 249 pp. \$14.99 (Paperback). ISBN: 978-0-06-154366-1.
}

\author{
Reviewed by \\ Quan Manh Ha \\ University of Montana
}

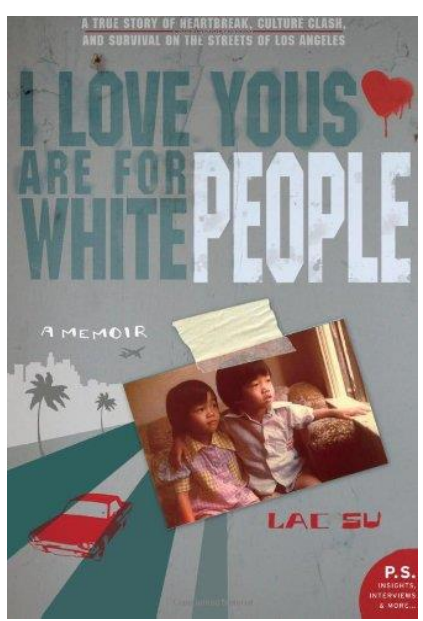

I Love Yous Are for White People recounts chronologically the childhood memories of the Vietnamese American narrator Lac Su (a.k.a. Big Head) and his traumatic relationship with Pa, Lac's "embarrassingly proud father" (p. 3). The opening of the book briefly summarizes Lac's family background in Vietnam before the unification of Vietnam in 1975. During the Vietnam War, Pa rose from orphanage and poverty to stability and prosperity by running a warehouse business, which made him the "embodiment of capitalism" (p. 40). He had served as a commander fighting the communists from the North militarily and supporting the former Saigon government politically. After the war ended, Lac's family fled Vietnam on a small, crowded fishing boat with other escapees and reached Hong Kong, before they relocated as refugees in California.

The narrative then focuses most specifically on Lac's and his family's life experience in the United States. The four members of his family — Lac, Pa, Ma (Lac's mother), and Quy (Lac's younger sister) - live in a small apartment in an old, squalid, and dilapidated brick building in Hollywood, and the five-year-old narrator witnesses various social ills in his neighborhood, where drug dealers, pimps, prostitutes, thieves, and gangs coexist. Thus, Pa does not allow his wife and children to leave the apartment while he is away looking for work, which makes Lac feel "suffocated and claustrophobic" (p. 28). The family's initial resettlement is fraught with misfortunes, language barriers, cultural misunderstandings, and discrimination. Despite the tribulations of life in exile, his parents emphasize the importance of education, the passport to a better life "in this white man's land" (p. 37). Lac studies at an American school, and he feels alienated from and rejected by his peers because of his lack of English proficiency and his Asian background. His parents become upset and frustrated at Lac's unsatisfactory academic work when they compare his performance to that of other Vietnamese children. Henceforth, Lac suffers from Pa's daily beatings and relentless criticism for being intellectually retarded and stupid. His parents superstitiously pray to their ancestors to elicit their blessings, and they force

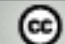

SORERIGHISRESERVEDReaders are free to copy, display, and distribute this article, as long as the work is attributed to the author(s) and the Journal of Southeast Asian American Education \& Advancement, it is distributed for noncommercial purposes only, and no alteration or transformation is made in the work. More details of this Creative Commons license are available at http://creativecommons.org/licenses/by-nc-nd/3.0/. All other uses must be approved by the author(s) or JSAAEA.

Journal of Southeast Asian American Education \& Advancement, Vol. 8 (2013) 
Lac to eat cow brain cooked with herbs, believing that the "vitamins" in this "medicine" will make their son smarter (pp. 66-67).

After the death of his infant brother, Zeal, the family moves to a new apartment, and they later are joined by Lac's cousin, named Crazy, who often harasses Lac sexually. Ma knows about Crazy's pedophilic behavior, but she hides it from $\mathrm{Pa}$, afraid that $\mathrm{Pa}$ will fly into a rage and kill Crazy. In the new neighborhood, Lac feels more welcome and comfortable because "people show interest in me and treat me kindly," but Pa insists that Lac socializes only with Asian kids (p. 81); Pa “doesn't trust whites, which to him means anyone who isn't Asian" (p. 82). Lac starts to hang out with a group of Chicano boys in the Kingsley Street Gang who try to convert Lac from an obedient child into a gang member. Pa becomes sick for a long time, which gives Lac complete freedom. Lac befriends Javi, a gang member. As Javi's "cash whore," or procurer of money, Lac steals his mother's food stamps and \$500 from his college fund to strengthen his camaraderie with Javi, thus supporting Javi's addiction in the arcade game Spy Hunter (p. 108). Later, when $\mathrm{Pa}$ discovers the financial losses, Lac is punished severely.

After this incident, $\mathrm{Pa}$ buys a used car and moves his family to Alhambra, east of Chinatown, "where other Asians dwell - a place where [Lac]'ll be protected from the white people" (p. 122). While his parents feel secure and inapprehensive about their new neighborhood, Lac does not enjoy being surrounded by Asian people because Asians "remind me of the ugliness of my own" (p. 123). Lac later states, "I've always associated the Vietnamese with the ugliness of my family and my embarrassment over my culture" (p. 139). Lac enrolls in a new junior high school but chooses to socialize with Mexican peers. The memoir and Chapter 9 have the same title. In this chapter, Lac is intrigued by his friends' celebration of Christmas, and when he talks to $\mathrm{Pa}$ about Christmas and present-giving, $\mathrm{Pa}$ ridicules his son for "getting influenced by the whites" because "boat people" have nothing to do with Christmas (pp. 145146). Lac is invited by his Mexican friend, Art, to his house for a Christmas party, and Lac is impressed by the way Art and his parents embrace the language of endearment. He contrasts the happy, affectionate atmosphere in Art's family with the suffocating, violent atmosphere in his own family, and Lac envies Art and his parents for their verbal communication characterized by such loving phrases, such as "I love you" and "Thank you". He does not understand why this kind of warm communication never occurs in his family. When Lac returns home, he imitates the way Art talks to his parents, by saying "I love you" to Pa, who rebuts:

What the fuck? Pa leaps up from the creeper and kicks it back against the garage door with his heel. He gets right in my face. Motherfuck! What did you just say? Who the fuck do you think you are? Who do you think $I$ am? Are you trying to imitate those white people by telling me those fucking words? Stop that shit! Don't you ever say those weak words to me ever again, you hear me? (p. 150)

Pa then sardonically calls Lac humiliating names and emphasizes to his son that love must be shown "through action" and not through words: "Words are useless - they do nothing but piss me $[\mathrm{Pa}]$ off" (p. 151).

Lac then befriends Dragon Head and joins the Street Ratz Gang. While he enjoys living his adolescent life of debauchery outside his home, beyond the control of $\mathrm{Pa}$, he continues to suffer from the domestic violence and turbulence within his family, primarily due to $\mathrm{Pa}$ 's disability and paranoia. $\mathrm{Pa}$ is an abusive husband and tiger father who runs the family like a tyrant. Lac's mother and siblings are victims of Pa's bad temper and unpredicted rage, and the 
atmosphere in the family is always tense. Lac does not live up to his parents' expectations - that is, to remain Asian and become educated but obedient; rather he lives a "thug life" (p. 167). Dragon Head and Snooky exercise extremely negative peer-influence upon Lac, teaching him to steal, drink, smoke, bully, lie, and devote his time to sex and truancy. Lac also becomes less fearful of Pa, probably because he has become inured to Pa's beatings and criticism.

Lac's parents then sponsor the emigration of Uncles Five and Nine to the United States, and the two uncles join the family. Lac often is included in the family's carousing parties. At school, Lac's grades do not improve, and after Lac is beaten by a girl-friend's brother in an alley on his way back from school, Pa decides to enroll his children in a new magnet school to avoid the troubles caused by thugs.

The Epilogue focuses on Lac's eventual visit to Vietnam and his adult reflections upon his childhood memories and relationship with $\mathrm{Pa}$. Lac travels to Vietnam to find and reclaim his Vietnamese roots, without informing $\mathrm{Pa}$ of the trip, because $\mathrm{Pa}$ will not allow Lac to make the journey. Due to the psychological wounds inflicted upon him, Lac decides to pursue a Ph.D. in industrial-organizational psychology at UC-Irvine, and later he gets married. He hopes that writing his memoirs will help him become a better father through coming to terms with the bitter-sweet, loving-abusive relationship between him and $\mathrm{Pa}$.

Su's I Love Yous Are for White People can be best categorized under the rubric of the literature of trauma, which focuses on the victim's painful experience and his/her writing down the traumatic memories in an attempt to make sense of the unpleasant past. Normally, it may take a victim ten to fifteen years to process the experience, and writing is an effective means to alleviate the psychological wounds. In an interview with Lac Su printed at the back of the book, the author states, "Even though this book was painful to write, it helped me to heal" ("At Last," p. 10). Su's memoir also can be categorized under the rubric of the literature of domestic realism, which generally focuses on relationships among family members and familial issues.

The memoir is a significant contribution to the corpus of Vietnamese American literature. The most important theme treated in the memoir is domestic violence. Within the Asian American community, domestic violence and child abuse are not uncommon, but they do not gain substantial public attention because generally Asian Americans consider parental discipline of children a private problem to be solved within the family. In the Introduction to Where Are You From? An Anthology of Asian American Writing, the editors Byron Wong, Larry Yu, and Valarie Katagiri (2012), observe, "It is a sad fact that Asian American women between the ages of fifteen and twenty-four have the highest suicide rates of any ethnicity. It is telling that Asian American males have fallen into a depressing cycle of violence" (p. 14). Patriarchy and Confucian values place the husband/father as the authority figure in the household, and thus his voice wields absolute power, while the voices of other family members are silenced. I Love Yous Are for White People stands as a literary testimony of domestic violence, as the narrator, his mother, and siblings are victimized by $\mathrm{Pa}$ 's tyranny. It should be noted that Pa's abusive behavior also results from the specific conditions of poverty and traumatic displacement that impact the arrival of many Southeast Asian refugees after the end of the Vietnam War. Thus, the memoir is a critique of structural inequalities, urban poverty, and the intersection between class, gender, and race in the contexts of war and its aftermath.

Gender relations is another theme that directly derives from aspects of Asian patriarchal culture. Throughout the memoir, Ma is submissive, docile, and stoic. Her opinions are not valued by $\mathrm{Pa}$ because he considers them to be intellectually inferior to his own. For instance, he arrogantly ascribes Lac's poor grades to Ma's lack of intelligence: "We know he got this from 
you. There's no way my genes produced such a stupid child" (p. 64). Although the narrator does not say that $\mathrm{Ma}$ is unhappy and resents $\mathrm{Pa}$, he has seen her crying, beaten by $\mathrm{Pa}$, several times. However, she seems to accept her role as a subservient woman without accusing her husband of his wrongdoings.

Su's portrayal of Pa substantiates several negative, biased stereotypes of Asian men: they are portrayed as asexual, stoic, emotionless, unromantic, and abusive. For instance, Mary Yu Danico and Frankin Ng (2004) observe that the U.S. media often present Asian men as "having no emotions" (p. 121). Derek Kenji Iwamoto and William Minh Liu (2009) further add that Asian men who are portrayed as manifesting high emotion sometimes are depicted as "wife beater[s]" or even as "deviant sexual aggressors" (p. 218). As mentioned above, Pa believes that Asians should not use affectionate expressions because they are meaningless. There is no romance in his marriage. His personality is complex: on the one hand, he works very hard for the well-being of his family and protects his children from dangers; on the other hand, he curses, scolds, and beats his children mercilessly. The image of home throughout the memoir does not symbolize warmth, protection, love; rather, home is an archive of trauma, danger, and violence.

Another prominent theme is the loss of innocence. Very early in his childhood in Vietnam, Lac already had seen such social ills as adultery, drinking, corruption, and blackmailing. He has also witnessed the cruelty of war: the sounds of firing, the explosion of grenades, and shootings. His perilous escape from Vietnam at the age of four is so haunting that he has "recurring nightmares" about the journey (p. 61). After the family's relocation in the United States, Lac experiences sexual molestation, mistreatment, and southern California's urban gang culture.

CNN interviewed the author about his book in 2011, and they discussed his father's tiger parenting with Amy Chua, author of the controversial Chinese American memoir Battle Hymn of the Tiger Mother. ${ }^{1}$ I Love Yous Are for White People is Lac Su's personal journey from domestic violence and "thug life" to self-healing and higher-education success.

Su's memoir addresses some of the many themes commonly found in ethnic American life-narratives, such as survival, alienation, loneliness, the desire to belong, cultural clash, displacement, generational conflict, and racial prejudice. Once they reach American soil, the United States is not the Promised Land that many refugees and immigrants had wished for and expected. The narrative tone is honest, sincere, and sometimes humorous, despite the narrator's sorrowful past. The heart-wrenching memoir represents Su's successful debut in writing, and it has attracted the attention of a wide and varied audience. It breaks new ground in Vietnamese American literature.

\section{References}

Danico, M. Y., \& Ng, F. (2004). Asian American issues. Westport, CT: Greenwood.

Iwamoto, D. K, \& Liu, W. M. (2009). Asian American men and Asianized attribution: Intersections of masculinity and sexuality. In N. Tewari and A. N. Alvarez (Eds.) Asian American psychology: Current perspectives (pp. 211-232). New York, NY: Psychology Press.

\footnotetext{
${ }^{1}$ This interview can be accessed at http://www.cnn.com/2011/OPINION/01/20/lac.su.tiger.mother.scars/index.html
} 
Wong, B., Yu, L., \& Katagiri, V. (2012). Introduction. In L. Yu and V. Katagiri (Eds.). Where are you from? An anthology of Asian American writing (pp. 11-15). Portland, OR: Thymos.

\section{About the Author}

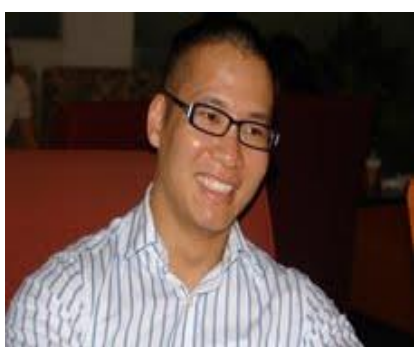

Quan Manh Ha, Ph.D., is Assistant Professor of English at the University of Montana. His research interests primarily focus on 20th-century and contemporary American literature, Vietnam War literature, ethnic studies, and literary translation. His publications have appeared in various journals and books, such as Short Story, Ethnic Studies Review, Southeast Review of Asian Studies, and Southern Humanities Review, etc. Currently, he is writing a book on the Vietnamese American short story and its writer. 


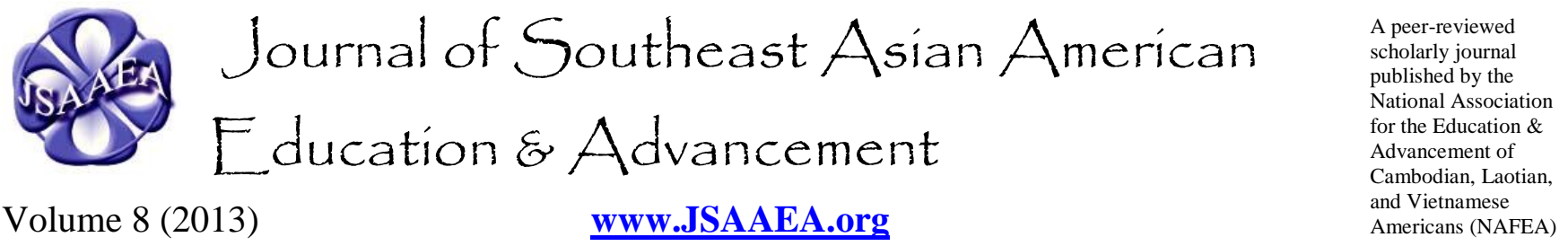

\author{
Editor \\ Dr. Wayne E. Wright \\ University of Texas, San Antonio \\ Associate Editors \\ Dr. Chhany Sak-Humphry \\ University of Hawaii at Manoa \\ Dr. Phitsamay Sychitkokhong Uy \\ University of Massachusetts, Lowell \\ Book Review Editor \\ Dr. Vichet Chhuon \\ University of Minnesota \\ Creative Works Editor \\ Bryan Thao Worra \\ Lao Assistance Center \\ Special Advisor \\ Gregory Green \\ Curator, Echols Collection on Southeast Asia, Cornell University Library \\ Journal Manager \\ Yeng Yang \\ University of Texas, San Antonio
}

Comments and questions for the editorial staff may be directed to jsaaea@ lists.sis.utsa.edu

\title{
Editorial Review Board
}

\author{
Dr. Steve Arounsack \\ California State University, Stanislaus \\ Dr. Phala Chea \\ Lowell Public Schools \\ Dr. Loan Dao \\ University of Massachusetts, Boston \\ Dr. Changming Duan \\ University of Missouri, Kansas City \\ Dr. Jeremy Hein \\ University of Wisconsin - Eau Claire \\ Dr. Samlong Inthaly \\ Minneapolis Public Schools \\ Dr. Kevin K. Kumashiro \\ University of Illinois, Chicago
}

\author{
Dr. Carl L. Bankston III \\ Tulane University \\ Dr. George Chigas \\ University of Massachusetts, Lowell \\ Dr. Hien Duc Do \\ San Jose State University \\ Dr. Sophal Ear \\ U.S. Naval Postgraduate School \\ Dr. Nancy H. Hornberger \\ University of Pennsylvania \\ Dr. Peter Nien-Chu Kiang \\ University of Massachusetts, Boston \\ Dr. Ha Lam \\ Arizona State University
}




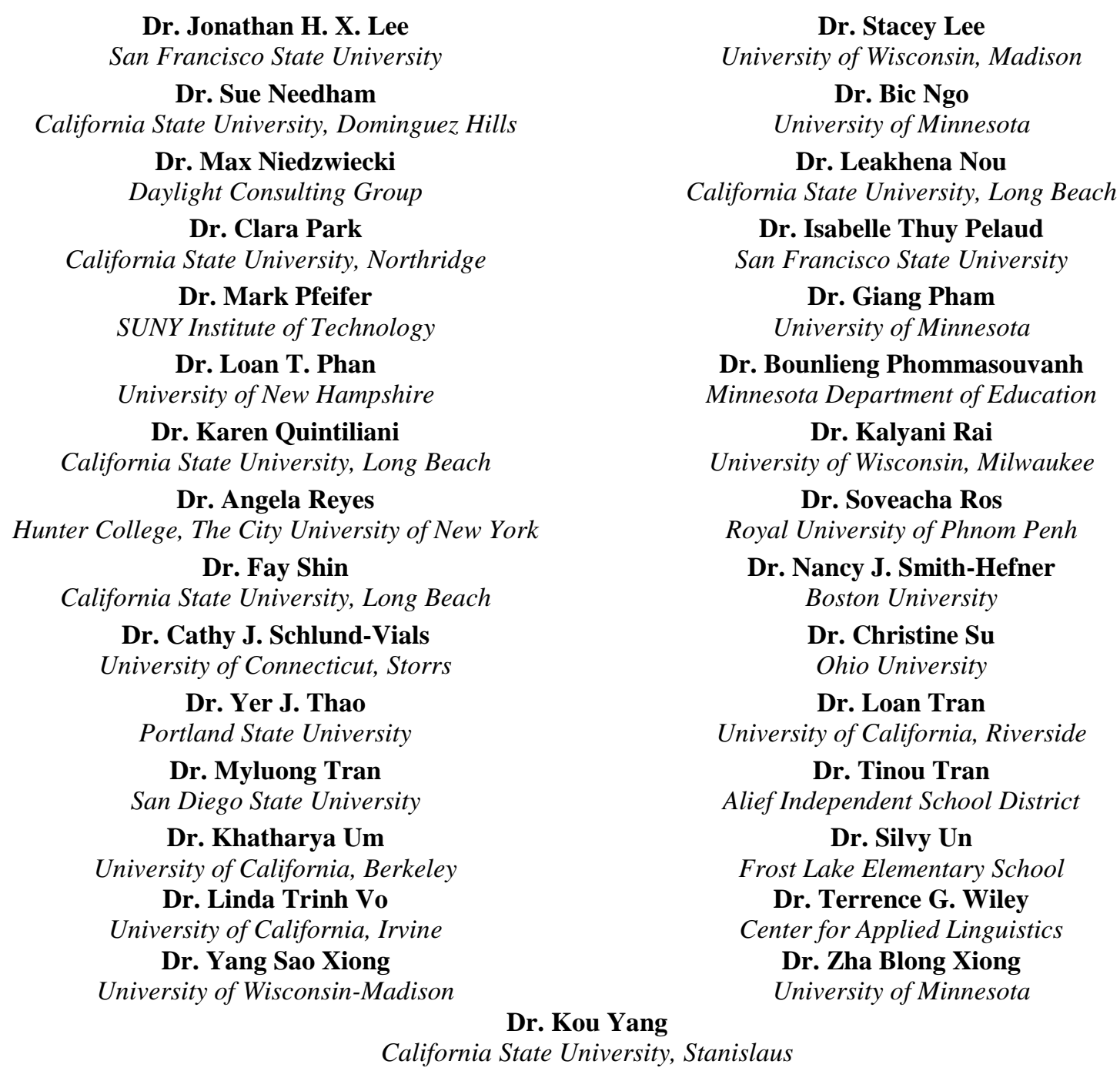

\section{Doctoral Student Editorial Review Board}

\author{
Sovicheth Boun \\ University of Texas, San Antonio \\ Keo Chea-Young \\ University of Pennsylvania \\ Ketmani Kouanchao \\ California State University, Fullerton \\ Ravy Lao \\ University of California, Santa Barbara \\ Minh Mai \\ University of Wisconsin-Madison \\ Hoa Nha Nguyen \\ Boston College \\ Vanna Som \\ Harvard University
}

\author{
Virak Chan \\ University of Texas, San Antonio \\ Annie BichLoan Duong \\ San Joaquin County Office of Education \\ Peter Tan Keo \\ Columbia University \\ Monirith Ly \\ Texas State University-San Marcos \\ Thien-Huong Ninh \\ University of Southern California \\ Malaphone Phommasa \\ University of California, Santa Barbara \\ Alisia Tran \\ University of Minnesota
}

Krissyvan Truong

Claremount Graduate University 